\title{
Expert System for Monitoring Elderly Health Using the Certainty Factor Method
}

\author{
Linda Marlinda ${ }^{1)^{*}}$, Widiyawati ${ }^{2)}$, Reni Widyastuti ${ }^{3)}$, Wahyu Indrarti ${ }^{4)}$ \\ ${ }^{1}$ STMIK Nusa Mandiri, Jakarta, ${ }^{2}$ STMIK Bani Saleh, Bekasi, ${ }^{3,4)}$ Universitas Bina Sarana Informatika, Jakarta \\ ${ }^{1)}$ linda.ldm@nusamandiri.ac.id, ${ }^{2)}$ widiyawati.zul@gmail.com, ${ }^{3)}$ reni.rws@bsi.ac.id,${ }^{4)}$ wahyu.wii@bsi.ac.id
}

Submitted : Sep 24, 2020 | Accepted : Oct 7, 2020 | Published : Oct 7, 2020

\begin{abstract}
A person who is in the elderly phase will experience various decreases, ranging from decreased memory or senility, hormone production, skin elasticity, muscle mass, bone density, strength and function of body organs, and the immune system. As a result, it is difficult for the elderly or the elderly to fight against various kinds of disease-causing bacteria or viruses, comorbidities, and adaptation to the social environment. Due to the complexity of this health problem, improvements can not only be made in the aspect of health services but also improvements in the environment and engineering of population factors or hereditary factors, but it is necessary to pay attention to behavioral factors that have a considerable contribution to the emergence of health problems. This research uses the certainty factor (CF) method which can provide a measure of belief in a symptom as a measure of how much the value is in the later diagnosis. The purpose of making this expert system is so that patients, patient families, and medical teams can monitor the health of the elderly daily. The results of this study indicate that using the CF method has an accuracy rate of 91 percent for the prediction of patients who have cholesterol
\end{abstract}

Keywords: Expert System; Certainty Factor; Health Monitoring; Elderly

\section{INTRODUCTION}

Everyone will experience aging. As we get older, the normal function of the body will decrease (Guizani \& Guizani, 2020). We will become physically weak and even some organs have been declared damaged by doctors. This will have an impact on a person's daily activities. The low immune system in the elderly also makes them more susceptible to various diseases (Yoon et al., 2018) (Song \& Yu, 2019).

Many people do not understand that the elderly are very susceptible to psychological problems, so they are prone to suffer from depression. The psychological problem of the elderly that is most often felt is loneliness. Loneliness arises as a result of being abandoned by spouses, peers, and families who have also passed away a lot, as well as children who have started living separately. This loneliness will cause grief and sadness to lead to depression(Kim, 2018)

The elderly are people aged 55 to 65 years and over and need special attention from family and the environment, especially their needs and health. Several aspects of the health of the elderly are increasingly vulnerable to various physical and psychological complaints (Piškur et al., 2014).

The development of information technology such as expert systems is needed to understand the world of health such as the elderly. Maintaining the physical health of the elderly to keep fit requires an expert system that will record and provide solutions to health workers or families, both current complaints, blood pressure, blood chemistry checks (cholesterol, blood sugar uric acid), and so on (Pramody, 2019). As well as monitoring the physical activity of the elderly and providing education about healthy lifestyles for the elderly.

The elderly will experience various decreased endurance and several diseases including tuberculosis, diarrhea, pneumonia, hepatitis, hypertension, stroke, Diabetes mellitus and arthritis, or rheumatism (Fatimah \& Alfiah, 2015). These diseases make them worry and are confused about how to handle them properly when they get a disease. So that this expert system can help the elderly and families to overcome the problems that arise above(Ashari, 2014).

The increasing number of elderly people can cause various problems such as medical problems (comorbidities), mental psychological, and socioeconomic. To overcome this, an expert system was created to monitor the health of the elderly. This system was created because of the low knowledge of the elderly and their families regarding disease information such as diabetes, cholesterol, gout, lack of motivation for the elderly to go to health centers due to distance from home, difficult economy, and lack of family support and closed elderly attitudes and behavior

* Corresponding Author 
Elderly

\section{LITERATURE REVIEW}

The elderly will usually experience aging which is marked by physical changes and decreased body function and several disease problems arise including (Marlinda, 2020)

1. Nutritional deficiencies, this problem is caused because the teeth are not working optimally so that the process of chewing food is not perfect. Other factors can also be caused by decreased function of soy sauce and smell which results in decreased appetite. Other factors such as living alone without accompanying family can also affect the nutritional intake of the elderly (Fatimah \& Alfiah, 2015) (Nikou et al., 2020).

2. Complementary diseases, namely metabolic diseases caused by decreased bodily functions such as hypertension and Diabetes Mellitus or as a complication of other diseases suffered by(Pramody, 2019).

3. Decreased Thinking Ability, namely decreased cognitive or thinking abilities of elderly people with dementia (Ushuluddin \& Samarinda, 2020).

4. Psychological problems feeling lonely because of the loss of a spouse, friends who begin to decrease, and children who do not live at home, feel unappreciated or respected and the emergence of diseases that limit movement so that the elderly lose their confidence(Tinggi \& Amanat, n.d.) (Gingras, 2020).

When a person enters old age there will be physical, psychological, and social changes. Physical changes include stamina and appearance so that some elderly people experience depression in work and social roles (Yoon et al., 2018). Economic change is related to social status and prestige in society as a retiree; changes in income because his life depends on pension benefits. Typical conditions similar to this decreased ability will give rise to a common symptom in elderly individuals, namely a feeling of fear of aging as long as they are not properly prepared (Sari \& Realize, 2019) (Padikkapparambil et al., 2020).

\section{Certainty factor $(\mathbf{C F})$}

The Certainty factor (CF) method is a method in the field of expert systems in part a clinical parameter value is given for the first time by MYCI to show the degree of trust in a field of expertise. This method can be used in the medical field to diagnose a disease (Padikkapparambil et al., 2020).

This uncertainty can be a probability that depends on the outcome of an event. Uncertainty results are caused by 2 factors, namely the uncertain rules of an uncertain user answer to a question posed by a system (Laksono et al., 2015). It can very easily be seen in a system for diagnosing a disease where the expert cannot define a relationship between symptoms and causes with certainty, and the patient cannot feel something with certainty, and ultimately generates many possible diagnoses (Sidabutar, 2019).

The CF method shows a measure of the certainty of a fact or rule. CF is a clinical parameter to indicate the magnitude of confidence (Yuhandri, 2018).

The advantages of the certainty factor method are:

1. CF method can measure something certain or uncertain in making decisions in the disease diagnosis expert system.

2. This method is suitable for use in expert systems that contain uncertainties in the medical field to diagnose a disease.

3. In one calculation process can only process two data so that the accuracy of the data can be maintained.

While the shortcomings of the certainty factor method are:

1. Uncertainty modeling using the certainty factor method is usually debated.

2. For data more than two pieces, data processing must be done several times.

\section{METHOD}

Certainty factor (CF) is a method in the field of expert systems in part a clinical parameter value that is given for the first time by the MYCI holder to show the trustworthiness in a particular field of expertise. This method can be used in the medical field to diagnose a disease (Yuhandri, 2018).

This uncertainty can be in the form of probability which depends on the outcome of an event. Uncertain results are caused by two factors: the uncertain rules of an uncertain user answer to a question raised by a system. This can be very easily seen in systems for diagnosing diseases where the experts cannot define a relationship between symptoms and their causes with certainty, and patients cannot feel things with certainty, and in the end result in many possible diagnoses(Widodo et al., 2020)(Yoon et al., 2018).

CF has the following rules, which consist of:

Rule 1

Certainty Factor for rules with single symptoms (single premise rule).

$$
[H, E] 1=C F[E] * C F[H]
$$


$\mathrm{CF}[\mathrm{H}, \mathrm{E}]$ : The certainty factor hypothesis which is influenced by evidence $\mathrm{E}$ (Facts) is known with certainty

$\mathrm{CF}[\mathrm{E}]$ : $\quad$ Certainty factor hypotheses are influenced by evidence $\mathrm{E}$ (Facts) from the user/patient

$\mathrm{CF}[\mathrm{H}]$ : $\quad$ Certainty factor hypotheses with the assumption of evidence known with certainty (Expert Value)

Rule 2

Certainty Factor for rules with similar conclusions (similary concluded rules) or more than one symptom

$$
\text { CFCombine } C F[H, E] 1,2=C F[H, E] 1+C F[H, E] 2 *(1-C F[H, E] 1)
$$

CFcombine: The combined results of the hypothesis

$\mathrm{CF}[\mathrm{H}, \mathrm{E}] 1$ : $\quad$ Certainty factor initial or old hypothesis in the results table from evidence $\mathrm{E}$ which is known with certainty

$\mathrm{CF}[\mathrm{H}, \mathrm{E}] 2$ : The next symptom hypothesis certainty factor is in the results table from evidence $\mathrm{E}$ which is known with certainty

Rule 3

Converts the certainty value into a percentage for easier understanding:

$$
\text { Confidence Percentage }=C F_{\_} \text {Combine } * 100 \%
$$

\section{RESULT}

the monitoring study for the elderly only discussed three gout, cholesterol and Diabetes melitus melitus with twenty-three symptoms, as below:

Table 1

Disease

\begin{tabular}{ll}
\hline Code & Name of Disease \\
\hline P01 & gout \\
P02 & Cholesterol \\
P03 & Diabetes mellitus \\
\hline
\end{tabular}

In table 1 the discussion of an expert system consists of three diseases, namely gout, cholesterol, diabetes mellitus. This disease mostly affects the elderly at home or at-home health and can be seen by the symptoms in Table 2.

Table 2

Disease Symptoms

\begin{tabular}{ll}
\hline Code & \multicolumn{1}{c}{ Disease Symptoms } \\
\hline G01 & Body temperature $36,5-37,2 \mathrm{C}$ \\
G02 & Blood pressure $80-120 \mathrm{~mm} \mathrm{Hg}$ \\
G03 & Blood sugar $70-130 \mathrm{mg} / \mathrm{dl}$ \\
G04 & Cholesterol 200-239 mg/dl \\
G05 & Gout 5,7 - 7,0 mg/dl \\
G06 & Heart Pressure $60-100 \mathrm{BPM}$ \\
G07 & Feeling a headache \\
G08 & Feeling Dizzy \\
G09 & Blurred Vision \\
G10 & Shortness of Breath \\
G11 & nyctalopia \\
G12 & pain in the joints \\
G13 & Stiffness in bone joints. \\
G14 & Chest pain \\
G15 & Often tired \\
G16 & A sense of aque in the nape \\
G17 & Weak leg muscles
\end{tabular}




\begin{tabular}{ll} 
G18 & Xanthelasma \\
G19 & Frequent urination \\
G20 & Fast hungry \\
G21 & Weight loss drastically \\
G22 & Hard-to-heal wounds \\
G23 & Red and swollen gums \\
\hline
\end{tabular}

Table 2 of the expert system contains twenty-three common symptoms commonly suffered by the elderly, namely Body temperature 36.5 - 37.2 C, Blood pressure 80-120 mm Hg, Blood sugar 70-130 mg/dl, Cholesterol 200- $239 \mathrm{mg} / \mathrm{dl}$, Gout 5,7 - 7,0 mg/dl, Heart Pressure 60 - 100 BPM, Feeling a headache, Feeling Dizzy, Blurred Vision, Shortness of Breath, nyctalopia, pain in the joints, Stiffness in bone joints, Chest pain, Often tired, Weak leg muscles, Xanthelasma, Frequent urination, Fast hungry, Weight loss drastically, Hard-to-heal wounds, Red and swollen gums, with each symptom, can be seen in table 3

Table 3

Expert Rule

\begin{tabular}{|c|c|c|c|}
\hline Code Symptoms & Gout & Cholesterol & Diabetes Mellitus \\
\hline G1 & $X$ & $X$ & $\mathrm{X}$ \\
\hline $\mathrm{G} 2$ & $\mathrm{X}$ & & \\
\hline G3 & $X$ & $X$ & $X$ \\
\hline G4 & $X$ & $X$ & $X$ \\
\hline G5 & & & $X$ \\
\hline G6 & & & $\mathrm{X}$ \\
\hline G7 & $\mathrm{X}$ & & \\
\hline G8 & $X$ & $\mathrm{X}$ & $X$ \\
\hline G9 & $X$ & & \\
\hline G10 & & & $X$ \\
\hline G11 & & & $X$ \\
\hline G12 & & & $X$ \\
\hline G13 & & & $\mathrm{X}$ \\
\hline G14 & $X$ & $\mathrm{X}$ & $X$ \\
\hline G15 & $X$ & $X$ & $X$ \\
\hline G16 & $X$ & $X$ & \\
\hline G17 & $\mathrm{X}$ & & $\mathrm{X}$ \\
\hline G18 & $X$ & $X$ & $X$ \\
\hline G19 & $\mathrm{X}$ & & \\
\hline $\mathrm{G} 20$ & $X$ & $X$ & \\
\hline G21 & $X$ & & \\
\hline G22 & $X$ & & \\
\hline G23 & $\mathrm{X}$ & $X$ & \\
\hline
\end{tabular}

Table 4

Prediction of Cholesterol disease symptoms

\begin{tabular}{llcr}
\hline Code & \multicolumn{1}{c}{ Symptoms } & Expert Value & Weight \\
\hline G02 & High Blood Pressure & 0.8 & 0.2 \\
& Headaches are gradually becoming more frequent & 0.4 & 0.8 \\
G08 & Dizziness, Nausea and vomiting without cause & 0.4 & 1 \\
G09 & Visual impairment & 0.5 & 0.6 \\
G10 & Shortness of Breath & 0.6 & 0.6 \\
G11 & Tingling on the hands or feet & 0.4 & 0.4 \\
G14 & Chest pain & 0.4 & 1 \\
G15 & Frequent Fatigue & 0.6 & 0.6 \\
G16 & A sense of a soreness at the nape & 0.4 & 0.4 \\
G18 & Xanthelasma & 0.4 & 0.2 \\
G19 & Frequent urination & 0.6 & 0.2 \\
\hline
\end{tabular}


Table 5

Combined CF Calculations

\begin{tabular}{rrrrr}
\hline CF1 & CF2 & $(1-$ CF1 & CF2 * (1-CF1) & $\begin{array}{r}\text { CF2 * (1-CF1) + } \\
\text { CF1 }\end{array}$ \\
\hline 0.32 & 0.40 & 0.68 & 0.27 & 0.59 \\
0.59 & 0.00 & 0.41 & 0.00 & 0.59 \\
0.59 & 0.36 & 0.41 & 0.15 & 0.74 \\
0.74 & 0.00 & 0.26 & 0.00 & 0.74 \\
0.74 & 0.40 & 0.26 & 0.10 & 0.84 \\
0.84 & 0.00 & 0.16 & 0.00 & 0.84 \\
0.84 & 0.16 & 0.16 & 0.03 & 0.87 \\
0.87 & 0.00 & 0.13 & 0.00 & 0.87 \\
0.87 & 0.30 & 0.13 & 0.04 & $\mathbf{0 . 9 1}$ \\
0.91 & 0.00 & 0.09 & 0.00 & $\mathbf{0 . 9 1}$ \\
\hline
\end{tabular}

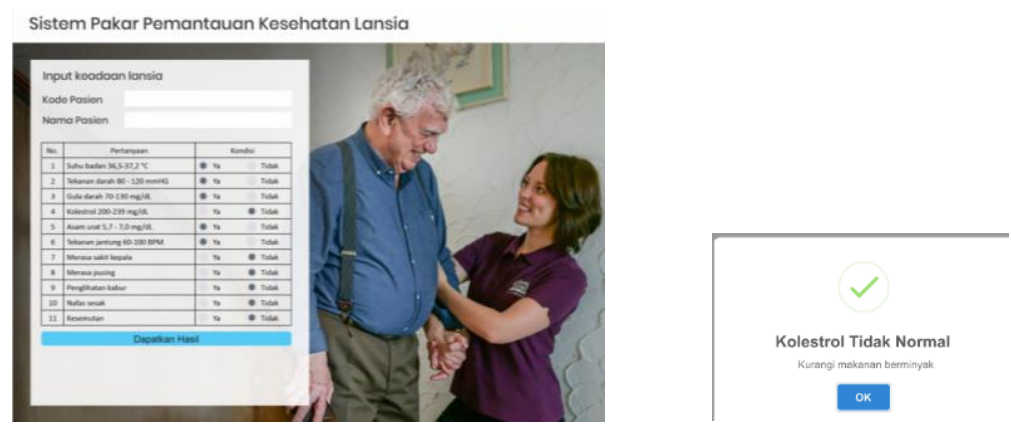

Fig. 1 Health Monitoring of Cholesterol elderly

Interface image 1, explaining the application of elderly expert system with abnormal Cholesterol results
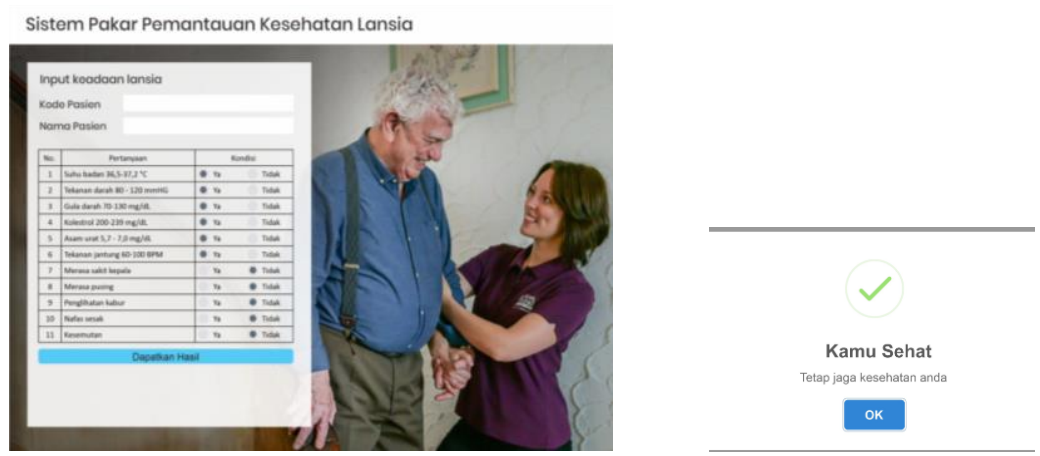

Fig. 2 Health Monitoring for healthy elderly

Interface image 1, explaining the application of the elderly expert system with the results of healthy seniors.Based on the above calculation obtained confidence prentasi for seniors who fill in the table above with high cholesterol condition of 91 percent

\section{DISCUSSIONS}

This paper applies a theoretical model of the adoption of digital health care technology that facilitates the independent living of the elderly. In particular, this system addresses health resource technology, giving people the freedom to live their lives in the way they see fit. The abilities that the elderly, families, and health workers acquire in the use of digital health care technology can provide the ability to live independently at home. In the following sections, we describe theoretical findings and contributions based on an expert theory using the Certainty factor method. We then discuss the research implications for practice, limitations, and suggestions for future research.. 


\section{CONCLUSION}

This expert system can monitor the health of the elderly with common symptoms they face such as Body temperature 36.5 - 37.2 C, Blood pressure 80-120 mm Hg, Blood sugar 70-130 mg/dl, Cholesterol 200-239 mg/dl, Gout 5,7 - 7,0 mg/dl, Heart Pressure 60 - 100 BPM, Feeling a headache, Feeling Dizzy, Blurred Vision, Shortness of Breath, nyctalopia, pain in the joints and others, if this system is filled by elderly people, nurses or family, the information will come out, the elderly are in good health or experiencing symptoms of diseases such as gout, cholesterol, and diabetes mellitus so that the elderly can be monitored for their health. The elderly can enjoy life, do sports regularly, have a healthy lifestyle, get enough rest. Based on respondents who filled in the expert system using the CF method, it was obtained calculations with results with a confidence level of 91 percent for predicting elderly patients who had cholesterol.

\section{REFERENCES}

Ashari, R. G. (2014). Memahami Hambatan dan Cara Lansia. 33, 155-170.

Fatimah, D. D. S., \& Alfiah, L. N. (2015). Perancangan Sistem Pakar Penyakit Pada Orang Lanjut Usia. Jurnal Algoritma, 14(2), 513-522. https://doi.org/10.33364/algoritma/v.14-2.513

Gingras, G. (2020). Toward a Non-intrusive , Affordable Platform for Elderly Assistance and Health Monitoring. 699-704. https://doi.org/10.1109/Compsac48688.2020.0-178

Guizani, K., \& Guizani, S. (2020). IoT Healthcare Monitoring Systems Overview for Elderly Population. 2020 International Wireless Communications and Mobile Computing, IWCMC 2020, 2005-2009. https://doi.org/10.1109/IWCMC48107.2020.9148446

Kim, J. H. (2018). Social Science \& Medicine Productive aging of Korean older people based on time use. Social Science \& Medicine, April, 0-1. https://doi.org/10.1016/j.socscimed.2018.04.020

Laksono, G. D., Syaifidin, Y. W., \& Astiningrum, M. (2015). Pengembangan Sistem Pakar Untuk Mendiagnosa Infeksi Saluran Pernafasan Akut (ISPA) Menggunakan Metode Certainty factor. Seminar Informatika.

Marlinda, L. (2020). A Selection Of ICT Based Social Media With Elderly Rural Women Using Profile Matching Methods. 29(7), 2856-2863.

Nikou, S., Agahari, W., Keijzer-Broers, W., \& de Reuver, M. (2020). Digital healthcare technology adoption by elderly people: A capability approach model. Telematics and Informatics, 53(September), 101315. https://doi.org/10.1016/j.tele.2019.101315

Padikkapparambil, J., Ncube, C., Singh, K. K., \& Singh, A. (2020). Internet of Things technologies for elderly health-care applications. In Emergence of Pharmaceutical Industry Growth with Industrial IoT Approach. Elsevier Inc. https://doi.org/10.1016/b978-0-12-819593-2.00008-X

Piškur, B., Daniëls, R., Marian, J., Ketelaar, M., Smeets, R. J. E. M., Norton, M., \& Beurskens, A. J. H. M. (2014). Participation and social participation: are they distinct concepts? https://doi.org/10.1177/0269215513499029

Pramody, R. (2019). Penerapan Metode Forward Chaining Pada Sistem Pakar Untuk Mendiagnosa Penyakit Degeneratif Pada Lansia Berbasis Web. JATI (Jurnal Mahasiswa Teknik Informatika), 3(1), 269-276.

Sari, M., \& Realize, R. (2019). Sistem Pakar Mendiagnosa Penyakit Osteoporosis pada Lansia Menggunakan Metode Forward Chaining Berbasis Web. Jurnal Ilmiah Informatika, 7(01), 24-30.

Sidabutar, R. M. (2019). Sistem Pakar Mendiagnosa Penyakit Sistem Kardiovaskuler Pada Lansia Dengan Menggunakan Metode Case Based Reasoning. Jurnal Riset Komputer (JURIKOM), 6(1), 93-99.

Song, D., \& Yu, D. S. F. (2019). Effects of a moderate-intensity aerobic exercise programme on the cognitive function and quality of life of community-dwelling elderly people with mild cognitive impairment: A randomised controlled trial. International Journal of Nursing Studies, 93, 97-105. https://doi.org/10.1016/j.ijnurstu.2019.02.019

Tinggi, S., \& Amanat, T. (n.d.). 1. Valentine Ibrahim, "Pendampingan Pastoral Bagi Kaum Lanjut Usia Dalam Menghadapi Kematian” (M.Div, Sekolah Tinggi Teologi Amanat Agung, 2018), 4. 1. 1-11.

Ushuluddin, F., \& Samarinda, I. (2020). Faktor-Faktor Penunjang Kebahagiaan A . Pendahuluan Manusia Pada Hakikatnya Akan Mengalami Proses Penuaan Atau Menjadi Tua. Penuaan Adalah Sebuah proses dimana seorang individu mengalami penurunan kemampuan pada setiap jaringan dalam tubuh. Individu yan. 1, 23-32.

Widodo, S., Utami, Y. T., \& Rosita, R. (2020). Application of Diet Program Monitoring Using Intelligent System. $8(2), 16-23$.

Yoon, H., Jang, Y., Vaughan, P. W., \& Garcia, M. (2018). Older Adults 'Internet Use for Health Information : Digital Divide by Race / Ethnicity and Socioeconomic Status. https://doi.org/10.1177/0733464818770772

Yuhandri, Y. (2018). Diagnosa Penyakit Osteoporosis Menggunakan Metode Certainty Factor. Jurnal RESTI (Rekayasa Sistem Dan Teknologi Informasi), 2(1), 422-429. https://doi.org/10.29207/resti.v2i1.349 